REVIEW ARTICLE

\title{
A Review of COVID-19 Clinical Presentation
}

\author{
Lokesh Shanmugam ${ }^{1}$, Arvind Visweshwar ${ }^{2}$
}

\begin{abstract} and presentation in pregnancy, children, and old age.

Keywords: COVID-19, Fever, Multisystem inflammatory syndrome in children.

SBV Journal of Basic, Clinical and Applied Health Science (2020): 10.5005/jp-journals-10082-02255
\end{abstract}

COVID-19 is a present pandemic infecting at exponential rates. Clinical presentations include fever, fatigue, myalgia, and dry cough; however, many atypical presentations have also been reported. COVID-19 is found to have cause pregnancy complications and is said to produce a multisystem inflammatory syndrome in children. This article is a review on clinical presentation of COVID-19 including its atypical presentation

\section{INTRODUCTION}

Coronaviruses were important human pathogens; ${ }^{1}$ however, by December 2019, a novel coronavirus which is designated as severe acute respiratory syndrome coronavirus 2 (SARS-CoV-2) was identified as the cause of a cluster of atypical pneumonia cases in Wuhan, China. ${ }^{2}$ It soon became a pandemic, infecting lakhs of people across the world and causing over 100,000 deaths worldwide. WHO declared COVID-19 a pandemic on March 11, $2020 .{ }^{3}$

\section{Incubation Period}

The incubation period of COVID-19 is thought to be 14 days. ${ }^{4-6}$ A study from China reported that symptoms would develop in $2.5 \%$ of infected individuals within 2 days and in $97.5 \%$ of infected individuals within 11 days and the median incubation period in this study was 5 days. ${ }^{7}$

\section{Risk Factors}

Comorbidities and other conditions that have been associated with severe illness and mortality include: ${ }^{8-11}$

- Age $>65$ years

- Preexisting pulmonary disease

- Chronic kidney disease

- Diabetes mellitus

- Hypertension

- Cardiovascular disease

- Obesity

- Immunosuppressant therapy

- Transplant history

- HIV, CD4 count $<299$ cells.

Among patients with advanced age and medical comorbidities, presentation was severe ${ }^{12}$ and according to the reports from China, Italy, and United States males had a higher number of deaths..$^{13-15}$

Particular laboratory features have also been found to be associated with worse outcomes. ${ }^{16-18}$ These include:

- Lymphopenia

- Elevated liver enzymes

- Elevated lactate dehydrogenase

- Elevated inflammatory markers

- Elevated D-dimer

- Elevated prothrombin time
1,2Department of General Medicine, Mahatma Gandhi Medical College
and Research Institute, Sri Balaji Vidyapeeth, Puducherry, India

Corresponding Author: Lokesh Shanmugam, Department of General Medicine, Mahatma Gandhi Medical College and Research Institute, Sri Balaji Vidyapeeth, Puducherry, India, Phone: +91 9791630480, e-mail: lokeshs@mgmcri.ac.in

How to cite this article: Shanmugam L, Visweshwar A. A Review of COVID-19 Clinical Presentation. J Basic Clin Appl Health Sci 2020; 3(2):44-46.

Source of support: Nil

Conflict of interest: None

- Elevated troponin

- Elevated creative phosphokinase

- Acute kidney injury.

\section{Clinical Presentation}

The presentation varies from mild to critical disease with majority being not severe. A report from Chinese Center for Disease Control and Prevention states that out of the 44,500 confirmed cases $81 \%$ were having no or mild symptoms of pneumonia and $14 \%$ had dyspnea and hypoxia and $5 \%$ developed respiratory failure and multiorgan dysfunction and overall fatality rate was found to be $2.3 \%{ }^{10}$

A study from New York showed out of the 2,634 patients hospitalized for COVID-19, 14\% were treated in intensive care unit and $12 \%$ received invasive mechanical ventilation and mortality rates among patients wanting ventilator support was $88 \% .^{13}$

According to Indian demographic report, $15.3 \%$ of patients required intensive care and $6.6 \%$ required mechanical ventilation. ${ }^{19}$

Pneumonia is the most frequent serious presentation of infection characterized by fever, cough, dyspnea, and bilateral infiltrates on X-ray. ${ }^{5,20,21}$ Other presenting features include upper respiratory tract symptoms, myalgia, and diarrhea. Development of dyspnea several days after the onset of clinical symptoms is suggestive of COVID-19 (Tables 1 and 2). Conjunctivitis has also been described as presenting feature of COVID-19. ${ }^{22}$

Dermatological findings, such as maculopapular rash, urticarial and vesicular eruptions, and transient livedo reticularis, have been reported. 23,24

(0) The Author(s). 2020 Open Access This article is distributed under the terms of the Creative Commons Attribution 4.0 International License (https://creativecommons. org/licenses/by-nc/4.0/), which permits unrestricted use, distribution, and non-commercial reproduction in any medium, provided you give appropriate credit to the original author(s) and the source, provide a link to the Creative Commons license, and indicate if changes were made. The Creative Commons Public Domain Dedication waiver (http://creativecommons.org/publicdomain/zero/1.0/) applies to the data made available in this article, unless otherwise stated. 
Table 1: Differences between influenza and COVID-19

\begin{tabular}{lll}
\hline & Influenza & COVID-19 \\
\hline Incubation period & $1-4$ days & $1-14$ days \\
Children & Important drivers & Less affected \\
Risk factors & $\begin{array}{l}\text { Children, pregnant } \\
\text { women, elderly and } \\
\text { underlying chronic illness }\end{array}$ & $\begin{array}{l}\text { Old age, } \\
\text { chronic } \\
\text { medical illness }\end{array}$ \\
$\begin{array}{ll}\text { Cardiovascular disease } \\
\text { and ARDS }\end{array}$ & $<10 \%$ & $30-35 \%$ \\
Case fatality rate & $<1 \%$ & $3-4 \%$ \\
\hline
\end{tabular}

ARDS, acute respiratory distress syndrome

Table 2: Differences in symptom presentation between influenza and COVID-19

\begin{tabular}{lcl}
\hline Symptoms & Influenza & COVID-19 \\
\hline Fever & $85-90 \%$ & $82-87 \%$ \\
Cough & $90-95 \%$ & $36-44 \%$ \\
Breathlessness & $60-70 \%$ & $40-50 \%$ of severe cases \\
Fatigue & $15-18 \%$ & $60-63 \%$ \\
Myalgia & $5-6 \%$ & $30-38 \%$ \\
Gastrointestinal symptoms & $12-15 \%$ & $30-35 \%$ \\
Rhinorrhea & $80 \%$ & $10 \%$ \\
Sore throat & $35 \%$ & $<5 \%$ \\
\hline
\end{tabular}

Several complications have been described:

- Acute respiratory distress syndrome $e^{17}$

- Arrhythmias $^{14}$

- Cardiogenic shock

- Pulmonary embolism. ${ }^{25}$

\section{COVID-19 And Influenza: Similarities AND Differences}

\section{Similarities}

- Disease presentation is similar.

- Produce respiratory illness with a wide range of severity.

- Transmitted by contact, droplets, and fomites.

- To prevent: hand hygiene and good respiratory etiquette (coughing into your elbow or into a tissue and immediately disposing of the tissue).

\section{Atypical Presentations}

\section{Arrhythmias in COVID-19}

Majority of patients with COVID-19 will not have any symptoms or signs of arrhythmias; however, arrhythmias may be seen in patients having other cardiovascular complications, such as myocardial infarction, electrolyte disturbances, and drugs, causing QT prolongation including hydroxychloroquine used in COVID-19 prophylaxis. Arrhythmias vary from atrial arrhythmias to lifethreating Torsades de pointes. Patients with Torsades de pointes may be hemodynamically stable on presentation, may remain stable, or may become unstable rapidly and without warning should be treated according to the usual treatment protocol. ${ }^{9}$

\section{Guillain-Barré Syndrome in COVID-19}

Guillain-Barré syndrome (GBS) was found in five patients from Italy. First symptoms of GBS were lower limb weakness and paresthesia in four patients and facial diplegia followed by ataxia and paresthesia in one patient. The interval between the onset of symptoms of COVID-19 and first symptom of GBS ranged from 5 to 10 days in those four patients. ${ }^{26}$

\section{Acute Myopericarditis in COVID-19}

Acute myopericarditis in COVID-19 was reported where the patient had only fever, fatigue, and dry cough with ECG showing diffuse ST elevation and elevated cardiac enzymes with normal coronary angiogram; however, cardiac MRI showed increased wall thickness with diffuse biventricular hypokinesis in apical segments with severe left ventricle (LV) systolic dysfunction, biventricular myocardial interstitial edema with circumferential pericardial effusion, these findings were consistent with acute myopericarditis. ${ }^{27}$

\section{Large Vessel Stroke in COVID-19}

Five cases of large vessel stroke were reported in patients younger than 50 years of age in United States. Patient initially had presented with cough, headache, and chills for 1 week and were tested positive for COVID-19. On admission, these five patients had mean National Institute of Health Stroke Scale (NIHSS) score was 17 , consistent with severe large vessel stroke with one patient having previous history of stroke. Apart from stroke, coagulopathy and vascular endothelial dysfunction have been proposed as complications of COVID-19. ${ }^{28}$

\section{COVID-19 in Pregnancy}

Pregnancy and childbirth do not necessarily increase the risk of COVID or worsen the clinical course in comparison with nonpregnant females. There are added issues in pregnancy, fever, and hypoxemia from severe pneumonia may increase the risks for preterm labor, premature rupture of membranes, and abnormal fetal heart rate patterns. Fever during the first trimester may be associated with an increased incidence of congenital anomalies like neural tube defects. ${ }^{29}$

\section{COVID-19 in Children}

COVID-19 does not have an age predilection, it can involve all age groups, and many studies have shown presentation in children. The symptoms of COVID-19 in children are very much similar to adults and appears to be milder in children than in adults, although severe cases have been reported. Fever and cough are the most common reported symptoms in children. In young infants, fever without an obvious source and minimal respiratory symptoms have also been seen. Less common symptoms included fatigue, rhinorrhea/nasal congestion, diarrhea, and vomiting.

One of the rare presentations of COVID-19 in children is pediatric multisystem inflammatory syndrome that has been reported in United States. It is also been called as multisystem inflammatory syndrome in children (MIS-C). Clinical features included persistent fever, hypotension, gastrointestinal symptoms, rash, and myocarditis; however, respiratory symptoms may not be more common. ${ }^{30}$

Case definition includes:

- Age $<21$ years.

- Documented fever $>100^{\circ} \mathrm{F}$ for $>24$ hours.

- Elevated $C$ reactive protein (CRP), erythrocyte sedimentation rate (ESR), D-dimer, lactate dehydrogenase (LDH).

- Involvement of $>3$ organ systems. 


\section{Conclusion}

Pandemic COVID-19 in young individuals may be asymptomatic or mild and may remain undiagnosed, whereas in old age it presents as a severe illness with atypical presentations also. In pregnant females, there is no vertical transmission proven so far; however, droplet transmission during feeding is possible and fever during the first trimester can produce neural tube defects; hence, a high index of suspicion and laboratory confirmation of COVID has to be initiated.

\section{References}

1. Weiss SR, Navas-Martin S. Coronavirus pathogenesis and the emerging pathogen severe acute respiratory syndrome coronavirus. Microbiol Mol Biol Rev 2005;69(4):635-664. DOI: 10.1128/MMBR.69.4.635664.20055.

2. World Health Organization. Director-General's remarks at the media briefing on 2019-nCoV on 11 February 2020. https://www.who.int/ $\mathrm{dg} /$ speeches/detail/who-director-general-s-remarks-at-the-mediabriefing-on-2019-ncov-on-11-february-2020 (Accessed on February 12, 2020).

3. World Health Organization (WHO). WHO Director-General's opening remarks at the media briefing on COVID-19-11 March 2020. Available at: https://www.who.int/dg/speeches/detail/who-directorgeneral-s-opening-remarks-at-the-media-briefing-on-covid-19-11march-2020 (Accessed on May 01, 2020).

4. Chan JF-W, Yuan S, Kok K-H, To KK-W, Chu H, Yang J, et al. A familial cluster of pneumonia associated with the 2019 novel coronavirus indicating person-to-person transmission: a study of a family cluster. Lancet Lond Engl 2020 15;395(10223):514-523. DOI: 10.1016/S01406736(20)30154-9.

5. Guan W-J, Ni Z-Y, Hu Y, Liang W-H, Ou C-Q, He J-X, et al. Clinical characteristics of coronavirus disease 2019 in China. N Engl J Med 2020;382(18):1708-1720. DOI: 10.1056/NEJMoa2002032.

6. Li Q, Guan X, Wu P, Wang X, Zhou L, Tong Y, et al. Early transmission dynamics in Wuhan, China, of novel coronavirus-infected pneumonia. N Engl J Med 2020;382(13):1199-1207. DOI: 10.1056/NEJMoa2001316.

7. Lauer $\mathrm{SA}$, Grantz KH, Bi Q, Jones FK, Zheng Q, Meredith HR, et al. The incubation period of coronavirus disease 2019 (COVID-19) from publicly reported confirmed cases: estimation and application. Ann Intern Med 2020;172(9):577-582. DOI: 10.7326/M20-0504.

8. Liang W, Guan W, Chen R, Wang W, Li J, Xu K, et al. Cancer patients in SARS-CoV-2 infection: a nationwide analysis in China. Lancet Oncol 2020;21(3):335-337. DOI: 10.1016/S1470-2045(20)30096-6.

9. Mehra MR, Desai SS, Kuy S, Henry TD, Patel AN. Cardiovascular disease, drug therapy, and mortality in COVID-19. N Engl J Med 2020;382(25):e102. DOI: 10.1056/NEJMoa2007621.

10. Wu Z, McGoogan JM. Characteristics of and important lessons from the coronavirus disease 2019 (COVID-19) outbreak in China: summary of a report of 72314 cases from the Chinese Center for Disease Control and Prevention. JAMA 2020;323(13):1239-1242. DOI: 10.1001/ jama.2020.2648.

11. Lighter J, Phillips M, Hochman S, Sterling S, Johnson D, Francois F, et al. Obesity in patients younger than 60 years is a risk factor for COVID19 hospital admission. Clin Infect Dis 2020. ciaa415. DOI: 10.1093/cid/ ciaa415.

12. McMichael TM, Currie DW, Clark S, Pogosjans S, Kay M, Schwartz NG, et al. Epidemiology of COVID-19 in a long-term care facility in king county, Washington. N Engl J Med 2020;382(21):2005-2011. DOI: 10.1056/NEJMoa2005412.

13. Richardson S, Hirsch JS, Narasimhan M, Crawford JM, McGinn T, Davidson KW, et al. Presenting characteristics, comorbidities, and outcomes among 5700 patients hospitalized with COVID-19 in the new york city area. JAMA 2020;323(20):2052-2059. DOI: 10.1001/ jama.2020.6775[EPub Ahead of Print].

14. Chen T, Wu D, Chen H, Yan W, Yang D, Chen G, et al. Clinical characteristics of 113 deceased patients with coronavirus disease 2019: retrospective study. BMJ 2020;368:m1091.

15. Onder G, Rezza G, Brusaferro S. Case-fatality rate and characteristics of patients dying in relation to COVID-19 in Italy. JAMA 2020;323(18): 1775-1776. DOI: 10.1001/jama.2020.4683.

16. Shi S, Qin M, Shen B, Cai Y, Liu T, Yang F, et al. Association of cardiac injury with mortality in hospitalized patients with COVID19 in Wuhan, China. JAMA Cardiol 2020. e200950. DOI: 10.1001/ jamacardio.2020.0950.

17. Wu C, Chen X, Cai Y, Xia J, Zhou X, Xu S, et al. Risk factors associated with acute respiratory distress syndrome and death in patients with coronavirus disease 2019 pneumonia in Wuhan, China. JAMA Intern Med 2020. e200994. DOI: 10.1001/jamainternmed.2020.0994.

18. Zhou F, Yu T, Du R, Fan G, Liu Y, Liu Z, et al. Clinical course and risk factors for mortality of adult inpatients with COVID-19 in Wuhan, China: a retrospective cohort study. Lancet Lond Engl 2020;395(10229):1054-1062. DOI: 10.1016/S0140-6736(20)30566-3.

19. www.coronavirus.in.gov. (Accessed on May 01, 2020).

20. Wang D, Hu B, Hu C, Zhu F, Liu X, Zhang J, et al. Clinical characteristics of 138 hospitalized patients with 2019 novel coronavirus-infected pneumonia in Wuhan, China. JAMA 2020;323(11):1061-1069. DOI: 10.1001/jama.2020.1585.

21. Chen N, Zhou M, Dong X, Qu J, Gong F, Han Y, et al. Epidemiological and clinical characteristics of 99 cases of 2019 novel coronavirus pneumonia in Wuhan, China: a descriptive study. Lancet Lond Engl 2020;395(10223):507-513. DOI: 10.1016/S0140-6736(20)30211-7.

22. Colavita F, Lapa D, Carletti F, Lalle E, Bordi L, Marsella P, et al. SARSCoV-2 isolation from ocular secretions of a patient with COVID-19 in Italy with prolonged viral RNA detection. Ann Intern Med 2020. M20-1176. DOI: 10.7326/M20-1176.

23. Galván Casas $C$, Català $A$, Carretero Hernández G, Rodríguez-Jiménez $P$, Fernández Nieto $D$, Rodríguez-Villa Lario $A$, et al. Classification of the cutaneous manifestations of COVID-19: a rapid prospective nationwide consensus study in Spain with 375 cases. $\mathrm{Br} J$ Dermatol 2020. DOI: 10.1111/bjd.19163.

24. Manalo IF, Smith MK, Cheeley J, Jacobs R. A dermatologic manifestation of COVID-19: transient livedo reticularis. J Am Acad Dermatol 2020;S0190-9622(20):30558. DOI: 10.1016/ j.jaad.2020.05.001.

25. Danzi GB, Loffi M, Galeazzi G, Gherbesi E. Acute pulmonary embolism and COVID-19 pneumonia: a random association? Eur Heart J 2020;41(19):1858. DOI: 10.1093/eurheartj/ehaa254.

26. Toscano G, Palmerini F, Ravaglia S, Ruiz L, Invernizzi P, Cuzzoni MG, et al. Guillain-Barré syndrome associated with SARS-CoV-2. N Engl J Med 2020;382(26):2574-2576. DOI: 10.1056/NEJMc2009191.

27. Inciardi RM, Lupi L, Zaccone G, Italia L, Raffo M, Tomasoni D, et al. Cardiac involvement in a patient with coronavirus disease 2019 (COVID-19). JAMA Cardiol 2020. DOI: 10.1001/jamacardio.2020.1096.

28. Oxley TJ, Mocco J, Majidi S, Kellner CP, Shoirah H, Singh IP, et al. Large-vessel stroke as a presenting feature of COVID-19 in the young. N Engl J Med 2020;382(20):e60. NEJM [Internet]. [cited 2020 May 17]. Available from: https://www.nejm.org/doi/full/10.1056/ NEJMc2009787.

29. Elshafeey F, Magdi R, Hindi N, Elshebiny M, Farrag N, Mahdy S, et al. A systematic scoping review of COVID-19 during pregnancy and childbirth. Int J Gynaecol Obstet 2020. DOI: 10.1002/ijgo.13182.

30. NYC Health. 2020 Health Alert \#13: Pediatric multi-system inflammatory syndrome potentially associated with COVID-19. Available at: https://www1.nyc.gov/site/doh/providers/resources/ health-alert-network.page (Accessed on May 07, 2020). 